\title{
Student Evaluations of Teaching Effectiveness: An Instrument to Increase Teaching Quality in Higher Education
}

\author{
Hamdi Serin ${ }^{1}$ \\ ${ }^{1}$ Tishk International University, Erbil, Iraq \\ Correspondence: Hamdi Serin, Tishk International University, Erbil, Iraq. \\ Email: hamdi.serin@ishik.edu.iq \\ Received: April 2, 2019 \\ Accepted: May 20, 2019 \\ Online Published: June 1, 2019 \\ doi: 10.23918/ijsses.v5i4p168

\begin{abstract}
Although student evaluations of teaching effectiveness remain a debated issue due to their reliability, validity and potential bias, they have been adapted as a part of quality assurance system in many universities and hold their primacy. Their widespread use is a useful source of data for universities to make personnel decisions; for lecturers to refine their teaching; and for students to make decisions on instructor and course selection. In the present study pre and post survey questionnaires were conducted among 325 students to reveal whether student evaluations of teaching effectiveness increase teaching and learning quality at a university. It was found that student feedback played an increasingly important role in the delivery of high-quality teaching.
\end{abstract}

Keywords: Student Evaluations, Teaching Quality, Teaching Effectiveness, Higher Education

\section{Introduction}

Though student evaluations on teaching effectiveness remain a keenly debated issue, they have become commonplace in learning institutions to improve quality of teaching (Mart, 2017). The use of student ratings has been criticized due to their reliability, validity and gender bias (Adams, 1997). That students observe their instructors in the classroom and assess their teaching competence questions the validity of student evaluations because students mostly care about their grades (Hornstein, 2017). The relationship between higher grades and higher student evaluations is well established in many studies (March \& Roche, 2000; Greenwald \& Gillmore, 1997). In addition, faculty members are concerned about the usefulness of student evaluations because they are of the opinion that students are not knowledgeable enough to evaluate teaching properly (Simpson \& Siguaw, 2000). However, students are in a better position to measure the performance of instructors because they attend their lectures and have an opportunity to observe their teaching effectiveness. Furthermore, students are the best judge of their learning (Machina, 1987). Student ratings of teaching have been central to a great number of universities; hence, they have become a part of their quality assurance system (Kwan, 1999). Quality assurance has been on the agenda of many universities to promote quality in education and the participation of students in the teaching evaluation process has gained momentum to foster the overall teaching quality. In the same line of thought, Oztas, Ozdemir and Mart (2017) argue that student feedback to measure teaching effectiveness correlates with the quality of teaching and learning. Thus study aims to explore the influence of student evaluations on teaching effectiveness in a university. 


\section{Literature Review}

While there is a large indication showing student evaluations as a valuable source of information to measure teaching effectiveness (Cohen, 1981; Calderon, Gabbin, \& Green, 1996; Mart 2017), considerable research indicates that student ratings may not be sufficient to evaluate teaching performance (Cashin, 1983; Centra, 1993). Advocating the latter idea, Seldin (1993) argues that students should not be allowed to judge subject matter knowledge of instructors. Nevertheless, there is a well-developed literature supporting the appropriateness of using student evaluations for enhancing teaching performance (Theall \& Franklin, 1991; Wilson, 1986). Regarding this issue, Yorke (2003) states that "the act of assessing has an effect on the assessor as well as the student. Assessors learn about the extent to which they [students] have developed expertise and can tailor their teaching accordingly (p. 482). Student evaluations reflect the perception of teachers' teaching styles, attitudes, course delivery and course format. It is important to note that student evaluations can provide (Marsh \& Roche, 1993):

1. Formative feedback for enhancing teaching effectiveness and course content

2. An idea about teaching effectiveness for promotion decisions

3. Information to students to make decisions about course and instructor selection

Student evaluations are the main tool used to measure teaching ability of instructors in higher education. A great number of universities administer them to provide feedback for their instructors to improve their teaching (Nargundkar \& Shrikhande, 2012). Chen and Hoshower (2003) assert that student evaluations are used for formative and summative measurements of teaching. Formative function gives an idea to instructors to modify their teaching styles and course delivery. It is worth noting that, student evaluations can be used as the primary source to help instructors improve their teaching performance (Arubayi, 1987). Instructors through using the data obtained from student evaluations can enhance their teaching performance by remediating their weaknesses (Mart, 2017). In addition, instructors can use the data to modify course content and structure (Simpson, 1995). Summative function on the other hand serves as feedback for administrative decisions. Universities use student evaluations for promotion and pay rise decisions (Kemp \& Kumar, 1990). Students can also attach great importance to summative function of evaluations while selecting instructors or courses (March \& Roche, 1993).

This study seeks to answer the following questions:

1. Do student evaluations impact teaching practices of instructors?

2. Do student evaluations of teaching effectiveness increase student learning?

\section{The Research Context}

Teaching effectiveness in a learning setting is generally measured by means of student questionnaire which is designed to reveal teaching styles and behaviors. Furthermore, student evaluations have the potential to provide meaningful input to determine learning and teaching. The study was conducted at a university which has 3000 students. Since its foundation, student feedback is an essential part of learning at the university to improve teaching practice; for that reason, it administers student course evaluations twice in a year. 325 students who were randomly selected from different departments participated in the study (freshmen). These 165 female and 160 male students' ages ranged between 19 and 25 with an average age 
of 22 years. The study was conducted in two academic terms; fall and spring. The participants were asked to rate 12 statements on a five-point scale on a continuum from strongly disagree to strongly agree at the beginning of the academic year. For this study only compulsory courses were selected. The purpose of the study was clearly explained to the students before they filled in the questionnaire. The pre-survey questionnaire was conducted in the classrooms one month after the start of fall term to reveal the views of the students about the benefits of student evaluations of teaching effectiveness. The same questionnaire was conducted again at the end of the academic year. Both pre and post survey questionnaires were carried out to unveil the attitudes of the students towards the use of student feedback to increase teaching quality. The university conducts student course evaluation questionnaire twice in a year in all departments before final examinations. In order to increase student participation, these course evaluations are kept brief. The students have to answer 10 questions in the student course evaluations administered by the university. After the pre-survey questionnaire online student course evaluations in both terms were administered. The results of the course evaluations are distributed to instructors as a means for course improvement. The survey questions used in this study and the course evaluation questionnaire used by the university are similar. The emphasis in the questionnaires was on teaching ability to avoid bias. The timeline for all these survey questionnaires are presented in Table 1.

Table 1: The timeline for student course evaluations at the university

\begin{tabular}{lll}
\hline \multicolumn{1}{c}{ Data Sources } & Administered by & \multicolumn{1}{c}{ Descriptions } \\
\hline Pre-survey questionnaire & the researcher & One month after start of fall term \\
Student course evaluation I & the university & In the middle of fall term \\
Student course evaluation II & the university & In the middle of spring term \\
Post-survey questionnaire & the researcher & At the end of spring semester \\
\hline
\end{tabular}

\section{Findings and Discussion}

Table 2: Summery of demographic information

\begin{tabular}{|l|c|c|c|c|}
\hline & $\mathrm{N}$ & Educational Stage & \multicolumn{2}{|c|}{ Gender } \\
\hline Computer Engineering & 25 & 1 & $\mathrm{~F}=12$ & $\mathrm{M}=13$ \\
\hline Civil Engineering & 25 & 1 & $\mathrm{~F}=11$ & $\mathrm{M}=14$ \\
\hline Architecture & 25 & 1 & $\mathrm{~F}=13$ & $\mathrm{M}=12$ \\
\hline Interior Design & 25 & 1 & $\mathrm{~F}=19$ & $\mathrm{M}=6$ \\
\hline Business \& Management & 25 & 1 & $\mathrm{~F}=9$ & $\mathrm{M}=16$ \\
\hline International Relation \& Diplomacy & 25 & 1 & $\mathrm{~F}=13$ & $\mathrm{M}=12$ \\
\hline Accounting & 25 & 1 & $\mathrm{~F}=12$ & $\mathrm{M}=13$ \\
\hline Law & 25 & 1 & $\mathrm{~F}=10$ & $\mathrm{M}=15$ \\
\hline English Language Teaching & 25 & 1 & $\mathrm{~F}=16$ & $\mathrm{M}=9$ \\
\hline Physics Education & 25 & 1 & $\mathrm{~F}=14$ & $\mathrm{M}=11$ \\
\hline Mathematics Education & 25 & 1 & $\mathrm{~F}=12$ & $\mathrm{M}=13$ \\
\hline Biology Education & 25 & 1 & $\mathrm{~F}=13$ & $\mathrm{M}=12$ \\
\hline Dentistry & 25 & 1 & $\mathrm{~F}=15$ & $\mathrm{M}=10$ \\
\hline
\end{tabular}


The demographic information for the participants is given in Table 2. Only freshmen participated in the study because it was thought that their motivation to measure teaching effectiveness would be higher. Moreover, it was the first time they were allowed to participate in the teaching evaluation process at the university.

Table 3: Survey questionnaire statements and the results

\begin{tabular}{|l|c|c|c|c|c|}
\hline & \multicolumn{2}{|c|}{ Pre-survey } & \multicolumn{2}{c|}{ Post-survey } & $\begin{array}{c}\text { Increased } \\
\text { by(percentage) }\end{array}$ \\
\hline & Mean & SD & Mean & SD & \\
\hline $\begin{array}{l}\text { Demonstrates good communication } \\
\text { skills }\end{array}$ & 2.62 & .842 & 4.37 & .950 & $68 \%$ \\
\hline $\begin{array}{l}\text { Creating a non-threatening } \\
\text { environment }\end{array}$ & 2.54 & .814 & 4.32 & .926 & $70 \%$ \\
\hline Open to point of view of student & 2.68 & .906 & 4.52 & .930 & $69 \%$ \\
\hline Makes the class interesting & 2.26 & .874 & 3.85 & .862 & $70 \%$ \\
\hline Promotes student learning & 2.51 & .922 & 4.36 & .914 & $73 \%$ \\
\hline $\begin{array}{l}\text { Stimulates students' intellectual } \\
\text { development }\end{array}$ & 1.79 & .786 & 3.10 & .842 & $73 \%$ \\
\hline Creates clear learning objectives & 2.63 & .866 & 4.46 & .850 & $70 \%$ \\
\hline Provides appropriate resources & 2.28 & .782 & 3.95 & .864 & $73 \%$ \\
\hline Makes clear presentations & 2.67 & .846 & 4.48 & .892 & $68 \%$ \\
\hline $\begin{array}{l}\text { Provides a meaningful feedback for } \\
\text { students }\end{array}$ & 2.50 & .796 & 4.14 & .858 & $66 \%$ \\
\hline $\begin{array}{l}\text { Gives assignments that match } \\
\text { learning Outcomes of the course }\end{array}$ & 2.36 & .842 & 4.10 & .824 & $73 \%$ \\
\hline $\begin{array}{l}\text { Provides opportunities for students } \\
\text { to practice what they have learnt }\end{array}$ & 2.24 & .754 & 3.90 & .856 & $74 \%$ \\
\hline
\end{tabular}

It goes without saying that students have valuable insights into teaching performed in the classroom; thus feedback to improve teaching can be given best by students. Evidently a majority of the students agreed that the use of student feedback supported teaching quality. Although a moderately high number of students showed disagreement in the preliminary results, it is worth noting that the responses heavily weighted on the positive side in the post survey questionnaire indicating that the students saw the benefits of student course evaluations. In other words, while pre-survey questionnaire results yielded that student course evaluations at the university received little attention from the students, post-survey questionnaire results indicated that student course evaluations were worth considering increasing teaching effectiveness. The students in this study agreed that student course evaluations at the university not only helped instructors improve their instruction but also student achievement. Simply put, the students took course evaluations seriously (Renaud \& Murray, 2005). These findings are consistent with the findings of Chen and Hoshower (2003) who indicate that student course evaluations can offer meaningful feedback about teaching effectiveness. 
Cashin (1988) stresses that student evaluations are useful and they can provide reliable, valid and biasfree data. Student evaluations of teaching effectiveness provide significant feedback (Bangert, 2006); therefore, they can be employed in higher education to increase teaching quality (Hammonds et al., 2016). Seldin (1999) reported a dean saying that "if I trust one source of data on teaching performance, I trust the students" (p. 15). In this study involving 325 undergraduate students at a university, it was also found that student evaluations of teaching effectiveness played a critical role in enhancing the quality of teaching and learning. Cohen (1981) states that "...student learning is the most important criterion of teaching effectiveness" (p. 283). The students in the post-survey questionnaire reported agreement that student course evaluations at the university helped instructors improve their teaching. The difference between pre and post survey questionnaires indicate that the feedback instructors received from the students motivated them to perform better teaching because it is evident that they utilized the data for developmental purposes.

\section{Conclusion}

Although the use of student evaluations has been criticized, it remains the main tool in measuring teaching competence of instructors in higher education. An entire assessment of important aspects cannot be conducted by means of student evaluations but they are useful to increase teaching quality. They have potential advantages to encourage instructors to improve their teaching which can lead to better student achievement. Student feedback on teaching effectiveness can provide meaningful data for instructors to modify their teaching practices and improve course delivery. Additionally, it should be noted that student evaluations can help with the development of course content.

\section{References}

Adams, J. V. (1997). Student evaluations: The ratings game. Inquiry, 1, 10-16

Arubayi, E. A. (1987). Improvement of instruction and teacher effectiveness: are student ratings reliable and valid? Higher Education,16 (3), 267-278.

Bangert, A. W. (2006). The development of an instrument for assessing online teaching effectiveness. Journal of Educational Computing Research, 35 (3), 227-244. doi:10.2190/B3XP-5K617Q07-U443.

Calderon, T. G., Gabbin, A. L. \& Green, B. P. (1996). A framework for encouraging effective teaching (St. Harrisonburg, VA, American Accounting Association Center for Research in Accounting Education, James Madison University).

Cashin, W. E. (1983). Concerns about using student ratings in community colleges, in: A. SMITH (Ed.) Evaluating faculty and staff: New directions for community colleges (San Francisco, CA, Jossey-Bass).

Cashin, W. E. (1988). Student ratings of teaching. A summary of research (IDEA paper No.20). Manhattan: Kansas State University, Division of Continuing Education. (ERIC Document Reproduction Service No. ED 302 567)

Centra, J. A. (1993). Reflective faculty evaluation. San Francisco, CA, Jossey-Bass.

Chen, Y., \& Hoshower, L. (2003). Student evaluation of teaching effectiveness: An assessment of student perception and motivation. Assessment \& Evaluation in Higher Education, 28(1), 7188.

Cohen, P. A. (1981). Student ratings of instruction and student achievement: A meta-analysis of multisection validity studies. Review of Educational Research, 51 (3), 281-309.

Greenwald, A. G., \& Gillmore, G. M. (1997). Grading leniency is a removable contaminant of student ratings. American Psychologist, 52, 1209-1217. 
Hammonds, F., Mariano, G., Ammons, G., \& Chambers, S. (2016). Student evaluations of teaching: Improving teaching quality in higher education. Perspectives: Policy and Practice in Higher Education, 1-8.

Hornstein, H. (2017). Student evaluations of teaching are an inadequate assessment tool for evaluating faculty performance. Cogent Education, 4, 1-8.

Kemp, B. W., \& Kumar, G. S. (1990). Student evaluations: are we using them correctly? Journal of Education for Business, 66 (2), 106-111.

Kwan, K. P. (1999). How fair are student ratings in assessing the teaching performance of university teachers? Assessment \& Evaluation in Higher Education, 24 (2), 181-195.

Machina, K. (1987). Evaluating student evaluations. Academe, 73(3), 19-22.

Marsh, H. W., \& Roche, L. (1993). The use of students' evaluations and an individually structured intervention to enhance university teaching effectiveness. American Educational Research Journal, 30 (1), 217-251.

Marsh, H. W., \& Roche, L. A. (2000). Effects of grading leniency and low workload on students' evaluations of teaching: Popular myth, bias, validity, or innocent bystanders? Journal of Educational Psychology, 92, 202-228.

Mart, C.T. (2017). Student evaluations of teaching effectiveness in higher education. International Journal of Academic Research in Business and Social Sciences, 7(10), 57-61.

Nargundkar, S., \& Shrikhande, M. (2012). An empirical investigation of student evaluations of instruction - The relative importance of factors. Decision Sciences Journal of Innovative Education, 10 (1), 117-135. doi:10.1111/j.1540-4609.2011.00328.x.

Oztas, A., Ozdemir, M., \& Mart, C.T. (2017). Perspectives on quality assurance in higher education in Iraq: A case study at Ishik University. International Journal of Academic Research in Business and Social Sciences, 7(9), 268-272.

Renaud, R.D., \& Murray, H. G. (2005). Factorial validity of student ratings of instruction. Research in Higher Education, 12, 929-953.

Seldin,P. (1993). The use and abuse of student ratings of professors. The Chronicle of Higher Education, 40 (1), p. A40.

Seldin, P. (1999). Changing practices in evaluating teaching: A practical guide to improving faculty performance and promotion/tenure decisions. Bolton, MA: Anker.

Simpson, R.D. (1995). Uses and misuses of student evaluations of teaching effectiveness. Innovative Higher Education, 20 (1), 3-5.

Simpson, P. M., \& J. A. Siguaw. (2000). Student evaluations of teaching: An exploratory study of the faculty response. Journal of Marketing Education, 22, 199-213.

Theall, M., \& Franklin, J. (1991). Using student ratings for teaching improvement. New Directions for Teaching and Learning, 48 (4), 83-96.

Wilson, R. C. (1986). Improving faculty teaching: Effective use of student evaluations and consultants. Journal of Higher Education, 57(2), 196-211.

Yorke, M. (2003). Formative assessment in higher education: Moves towards theory and the enhancement of pedagogic practice. Higher Education, 45(4), 477-501. 